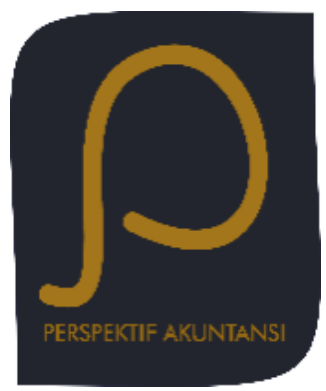

Perspektif Akuntansi

Volume 3 Nomor 3 (Oktober 2020), hal. 179-196

ISSN: 2623-0194 (Print), 2623-0186 (Online)

Copyright(C The Authors(s). All Rights Reserved

Center for Accounting Development and Research (CARD)

Program Studi Akuntansi

Fakultas Ekonomika dan Bisnis,

Universitas Kristen Satya Wacana

DOI: https://doi.org/10.24246/persi.vXiX.p179-196

http://ejournal.uksw.edu/persi

\title{
Survei Kecurangan Akademik Pada Mahasiswa Program Studi
} Akuntansi

\author{
Angeline \\ Septian Bayu Kristanto ${ }^{1}$ \\ Subagyo \\ Universitas Kristen Krida Wacana
}

Received

$19 / 06 / 2020$

Revised

24/08/2020

Accepted

$27 / 06 / 2020$
Abstract. This research aims to determine how the influence between the greed, opportunity, needs, disclosure and whistleblower of academic fraud on college students of the Accounting Study Program at the Faculty of Economics and Business, Krida Wacana Christian University (FEB UKRIDA). Respondents in this research were 147. The sampling technique using purposive sampling. The method of analysis used is multiple linear regression analysis. The results of this research indicate that there is a positive and significant influence between the variables of greed, opportunity, disclosure and academic fraud on college students of the Accounting Study Program at the FEB UKRIDA. In addition, there is a positive and not significant influence between variable needs and academic fraud. While the whistleblower variable has a negative and not significant effect to academic fraud.

Keywords : Academic Fraud, College Students, Greed, Opportunity, Needs, Exposure, and Whistleblower. 


\begin{abstract}
Abstrak. Penelitian ini bertujuan untuk mengetahui bagaimana pengaruh antara keserakahan, kesempatan, kebutuhan, pengungkapan dan whistleblower terhadap kecurangan akademik pada mahasiswa Program Studi Akuntansi Fakultas Ekonomi dan Bisnis Universitas Kristen Krida Wacana (FEB UKRIDA). Responden dalam penelitian ini sebanyak 147 mahasiswa. Teknik pengambilan sampel dengan menggunakan purposive sampling. Metode analisis data dalam penelitian ini menggunakan uji analisis regresi linier berganda. Hasil penelitian ini menunjukkan terdapat pengaruh positif signifikan antara variabel keserakahan, kesempatan, dan pengungkapan terhadap kecurangan akademik mahasiswa Program Studi Akuntansi FEB UKRIDA. Selain itu, variabel kebutuhan berpengaruh positif tidak signifikan terhadap kecurangan akademik pada mahasiswa Program Studi Akuntansi FEB UKRIDA. Sedangkan variabel whistleblower berpengaruh negatif tidak signifikan terhadap kecurangan akademik pada mahasiswa Program Studi Akuntansi FEB UKRIDA.
\end{abstract}

Kata kunci: kecurangan akademik, mahasiswa, keserakahan, kesempatan, kebutuhan, pengungkapan, dan whistleblower.

\title{
Pendahuluan
}

Menurut Undang-Undang No. 20 Tahun 2003 tentang Sistem Pendidikan Nasional Pasal 1 menjelaskan bahwa Pendidikan adalah upaya secara sadar dan terencana dalam rangka menciptakan situasi belajar dan proses pembelajaran supaya peserta didik terlibat secara aktif dalam mengembangkan kemampuan dirinya agar mendapat kekuatan baik dalam pengendalian diri, spiritual keagamaan, kecerdasan, kepribadian, akhlak mulia, dan keterampilan yang diperlukan bagi dirinya, masyarakat, serta bangsa dan negara. Dijelaskan juga pada Pasal 14 bahwa jenjang pendidikan terdiri dari pendidikan dasar, pendidikan menengah, dan pendidikan tinggi.

Pada Undang-Undang Nomor 12 Tahun 2012 tentang Pendidikan Tinggi Pasal 1 ayat 13 dan 15 mengemukakan sivitas akademika terdiri dari dosen dan mahasiswa yang merupakan peserta didik pada jenjang Pendidikan Tinggi. Pendidikan Tinggi harus berasaskan kejujuran sesuai pada Pasal 3 bagian c, berarti mahasiswa haruslah menjunjung tinggi nilai kejujuran selama menjalani perkuliahan. 
Namun hasil survei yang dilakukan oleh Little Circle Foundation (2015) menunjukkan bahwa lebih dari 92\% Mahasiswa dari Universitas Udayana pernah menyontek saat ujian. Dari angka tersebut menunjukkan bahwa sebagian besar mahasiswa sudah terbiasa melakukan kecurangan akademik. Menurut Munirah dan Nurkhin (2018) kecurangan akademik merupakan perbuatan tidak terpuji yang dilakukan oleh peserta didik dalam menjalani kegiatan akademik. Dengan melakukan hal tersebut menunjukkan bahwa para mahasiswa sudah meninggalkan nilai kejujuran.

Apabila mahasiswa mempertahankan perilaku ini maka disaat mereka sudah berada di dunia kerja nanti ditakutkan akan terbiasa untuk melakukan kecurangan. Terutama apabila seorang mahasiswa dari jurusan akuntansi yang nanti menjadi seorang akuntan maka mereka harus berintegritas dengan salah satunya adalah bersikap jujur yang sesuai dengan Etika Profesi Akuntan yang ditetapkan oleh Ikatan Akuntan Indonesia (2016).

Menurut Munirah dan Nurkhin (2018) beberapa faktor yang mempengaruhi terjadinya perilaku kecurangan akademik mahasiswa dapat dikaitkan dengan GONE Theory yang dikemukakan oleh Jack Bologna (1993) yaitu terdiri dari keserakahan (greed), kesempatan (opportunity), kebutuhan (need), dan pengungkapan (exposure). Keserakahan (greed) berhubungan dengan perilaku serakah yang berpotensi di dalam diri setiap individu. Kesempatan (opportunity) berhubungan dengan keadaan suatu organisasi sehingga individu berpeluang melakukan tindak kecurangan. Kebutuhan (need) adalah indikator yang diperlukan oleh individu untuk memenuhi kebutuhan hidup yang memadai. Dan terakhir pengungkapan (exposure) berhubungan dengan konsekuensi yang akan dikenakan kepada pelaku kecurangan apabila seorang individu diketahui telah melakukan kecurangan.

Dengan adanya tingkat kecurangan akademik antar mahasiswa yang tinggi, maka mahasiswa harus mengambil tindakan untuk mengurangi kebiasaan tersebut salah satunya dengan menjadi whistleblower. Definisi whistleblower adalah seseorang yang melakukan whistleblowing. Menurut Mustapha dan Siaw (2012) Whistleblowing adalah pengungkapan yang dilakukan oleh anggota organisasi atas tindakan illegal. Whistleblowing di kalangan mahasiswa dapat dilakukan dengan melaporkan sesama mahasiswa yang terbukti melakukan kecurangan.

Penelitian yang dilakukan oleh Mustapha dan Siaw (2012) menunjukkan hasil bahwa mahasiswa akhir dari Universitas Negeri di Malaysia yang bersedia menjadi seorang whistleblower tidak melakukan kecurangan akademik. Tingkat kecurangan akademik dapat menurun apabila ada seorang whistleblower dikarenakan setelah kecurangan yang dilakukan oleh salah satu mahasiswa terungkap, maka pihak universitas akan memberikan sanksi dan membuat mahasiswa lain akan takut untuk melakukan perilaku kecurangan. Maka dari itu dibutuhkan penelitian yang lebih lanjut mengenai hal ini terkait kesediaan mahasiswa untuk melakukan whistleblowing. 
Penelitian ini adalah kombinasi dari Penelitian Munirah dan Nurkhin (2018) serta Mustapha dan Siaw (2012). Dengan tingginya angka kecurangan akademik maka penelitian ini tertarik untuk melakukan penelitian terkait faktor-faktor kecurangan akademik pada mahasiswa menggunakan GONE Theory. Alasan penelitian ini memilih GONE Theory sebagai faktor untuk menganalisis kecurangan akademik karena teori ini sudah terkenal dalam meneliti penyebab fraud. Keserakahan dalam akademik adalah perilaku serakah yang berpotensi di dalam diri mahasiswa. Kesempatan berhubungan dengan keadaan suatu universitas sehingga mahasiswa berpeluang melakukan tindak kecurangan. Kebutuhan adalah indikator yang diperlukan oleh mahasiswa untuk memenuhi kebutuhan yang memadai akademiknya. Pengungkapan berhubungan dengan konsekuensi yang akan dikenakan kepada mahasiswa apabila mahasiswa diketahui telah melakukan kecurangan.

Peneliti juga meneliti kesediaan mahasiswa untuk menjadi whistleblower dalam rangka mengurangi tingkat kecurangan akademik. Maka dari itu perumusan masalah yang dapat diambil dalam penelitian ini adalah sebagai berikut: (1) Apakah keserakahan berpengaruh terhadap kecurangan akademik? (2) Apakah kesempatan berpengaruh terhadap kecurangan akademik? (3) Apakah kebutuhan berpengaruh terhadap kecurangan akademik? (4) Apakah pengungkapan berpengaruh terhadap kecurangan akademik? (5) Apakah whistleblower berpengaruh terhadap kecurangan akademik?

\section{Telaah Pustaka}

\section{GONE Theory}

GONE Theory adalah teori yang sering digunakan untuk meneliti faktor-faktor penyebab terjadinya tindakan fraud (Isgiyata et al., 2018). GONE Theory ditemukan oleh Jack Bologna pada tahun 1993. GONE Theory menjelaskan empat faktor penyebab terjadinya perilaku kecurangan yang terdiri dari: (a) Keserakahan (Greed), berhubungan dengan sifat serakah dan rakus dari para pelaku kecurangan yang berpotensi dalam diri setiap individu. (b) Kesempatan (Opportunity), berhubungan dengan adanya peluang untuk melakukan tindak kecurangan diakibatkan keadaan suatu organisasi/instansi atau lingkungan sekitar yang menyediakan kesempatan bagi individu untuk berperilaku curang. (c) Kebutuhan (Need), sifat seseorang ketika individu merasa tidak cukup akan keadaannya, bersikap konsumerisme, dan selalu menganggap kebutuhannya tidak akan pernah usai. Dan (d) Pengungkapan (Exposure), berhubungan dengan hukuman yang akan diterima oleh individu apabila tertangkap telah berbuat curang.

Keserakahan berasal dari kata serakah, arti serakah menurut Kamus Besar Bahasa Indonesia adalah selalu hendak memiliki lebih dari yang dimiliki. Keserakahan membahas tentang perilaku serakah yang berpotensi di dalam diri seseorang (Isgiyata et al., 2018). Keserakahan merupakan faktor individu, faktor ini melekat pada diri setiap orang. Keserakahan adalah salah satu indikator pendorong individu untuk melakukan tindak kecurangan dikarenakan pada dasarnya manusia 
mempunyai sifat serakah dan tidak pernah merasa puas atas apa yang telah dimilikinya (Budiman, 2018).

Kesempatan menurut Kamus Besar Bahasa Indonesia adalah mempergunakan peluang. Kesempatan merupakan kondisi yang memungkinkan individu dalam berbuat curang dan dianggap aman bagi seseorang dalam melakukan kecurangan (Albercht et al., 2012). Dasar pemikirannya adalah semakin besar kesempatan yang tersedia maka semakin besar pula peluang untuk melakukan sesuatu. Kesempatan adalah komponen penting dari perilaku fraud dikarenakan apabila seorang pelaku fraud tidak mempunyai kesempatan untuk melaksanakan aksinya, maka fraud tidak mungkin untuk dilakukan.

Kebutuhan adalah segala sesuatu keperluan manusia agar dapat mempertahankan hidupnya serta memperoleh kesejahteraan dan kenyamanan (Munirah dan Nurkhin, 2018). Kebutuhan dapat diartikan juga sebagai salah satu faktor psikologis yang menggerakan makhluk hidup dalam melakukan aktivitasnya dan menjadi acuan untuk bertindak. Menurut Dewi (2016) kebutuhan adalah indikator yang berkaitan dengan pelaku kecurangan itu sendiri (disebut sebagai faktor individual). Faktor individual merupakan perilaku yang melekat kepada individu itu sendiri, faktor individual ini berhubungan dengan moralitas.

Pengungkapan menurut Kamus Besar Bahasa Indonesia adalah proses, cara, perbuatan untuk membuka atau mengungkap sesuatu. Pengungkapan adalah konsekuensi atau sanksi yang dihadapi oleh pelaku kecurangan apabila pelaku ditemukan melakukan kecurangan (Budiman, 2018). Pengungkapan merupakan faktor yang berhubungan dengan organisasi sebagai korban perbuatan fraud yang dapat disebut sebagai faktor generik (Artantri, 2016).

Menurut Ratnawati (2016) sanksi yang dikenakan pada pelaku jika tertangkap berbuat curang dalam pengungkapan kecurangan masih kurang efektif untuk mencegah terjadinya peristiwa ini terulang di masa depan. Oleh karena itu diperlukan sanksi yang jelas terhadap tindakan dengan sanksi tersebut diterapkan sesuai ketentuan yang berlaku.

\section{Kecurangan Akademik}

Menurut Winardi et al. (2017) kecurangan akademik adalah tindakan tidak etis yang dilakukan oleh siswa ketika mereka merasionalisasi perilakunya sebagai hal yang wajar. Kecurangan akademik dianggap sebagai hambatan moral bagi siswa yang melakukan tindakan tersebut. Kecurangan akademik dapat diartikan juga sebagai perbuatan atau upaya penipuan yang dilakukan oleh siswa dengan menggunakan cara ilegal dan tidak dapat diterima dalam peraturan akademik (Nurharjanti, 2017). Jadi, dapat disimpulkan bahwa kecurangan akademik adalah perbuatan tidak jujur yang dilakukan dengan unsur kesengajaan untuk menipu dalam rangka mencapai keberhasilan akademis. 


\section{Whistleblower}

Whistleblowing (pelaporan pelanggaran) didefinisikan sebagai pengungkapan oleh anggota organisasi tentang praktik ilegal, tidak bermoral atau tidak sah yang dilakukan seseorang seperti tindakan korupsi, pemborosan, penipuan, salah urus atau penyalahgunaan wewenang yang bertentangan dengan hukum, baik dalam sektor publik maupun swasta (Mustapha dan Siaw, 2012). Whistleblowing adalah proses kompleks yang melibatkan faktor individu dan organisasi. Individu yang melaporkan tindak kecurangan disebut dengan whistleblower. Seorang whistleblower biasanya memiliki bukti yang cukup relevan terkait perilaku yang melanggar hukum tersebut (Nurharjanti, 2017). Peran seorang whistleblower sangatlah penting karena biasanya seorang whistleblower berasal dari organisasi yang sama dengan pelaku, sehingga benar-benar mengetahui bagaimana seluk beluk dari tindakan kecurangan yang dilakukan oleh pelaku.

Nurharjanti (2017) berpendapat bahwa masih banyak orang yang kurang berani untuk melaporkan tindak pelanggaran dikarenakan adanya resiko yang dihadapi. Bentuk resiko tersebut seperti diasingkan oleh rekan sesama organisasi sampai adanya ancaman yang membuat whistleblower menjadi khawatir akan keselamatan dirinya sendiri. Namun saat ini jaminan keamanan dan perlindungan hukum kepada whistleblower sudah ada sejak munculnya UU 13 Tahun 2006 tentang Perlindungan Saksi dan Korban. Dengan munculnya undang-undang tersebut dapat menjadi salah satu motivasi whistleblower untuk melaporkan tindak kecurangan karena adanya perlindungan bagi pelapor pelanggaran.

\section{Pengembangan Hipotesis}

\section{Pengaruh keserakahan terhadap kecurangan akademik}

Keserakahan membuat seseorang cenderung untuk melakukan kecurangan dikarenakan sifat tidak pernah merasa puas atas apa yang telah dimilikinya. Hal ini didukung oleh hasil penelitian yang dilakukan Indrawati et al (2017) serta Munirah dan Nurkhin (2018) yaitu keserakahan memiliki pengaruh positif dan signifikan terhadap kecurangan akademik. Namun penelitian yang dilakukan oleh Budiman (2018) menunjukkan bahwa keserakahan berpengaruh positif dan tidak signifikan perilaku kecurangan akademik. Berdasarkan penjelasan di atas, maka perumusan hipotesis sebagai:

$\boldsymbol{H}_{1}$ : Keserakahan berpengaruh positif signifikan terhadap kecurangan akademik

\section{Pengaruh kesempatan terhadap kecurangan akademik}

Kesempatan membuat seseorang dapat berlaku curang dikarenakan adanya peluang untuk melakukan kecurangan tersebut. Pernyataan ini didukung oleh hasil penelitian yang dilakukan oleh Indrawati et al (2017) serta Munirah dan Nurkhin (2018) yaitu kesempatan memiliki pengaruh positif dan signifikan terhadap kecurangan akademik. Sedangkan penelitian yang dilakukan oleh Budiman (2018) menunjukkan bahwa kesempatan berpengaruh positif dan tidak signifikan terhadap perilaku 
kecurangan akademik. Berdasarkan penjelasan diatas, maka perumusan hipotesisnya adalah:

$\boldsymbol{H}_{2}$ : Kesempatan berpengaruh positif signifikan terhadap kecurangan akademik

\section{Pengaruh kebutuhan terhadap kecurangan akademik}

Kebutuhan dapat membuat seseorang berlaku curang karena adanya suatu keperluan sehingga memaksa individu tersebut untuk melakukan kecurangan. Hal ini didukung oleh hasil penelitian yang dilakukan oleh Indrawati et al (2017) serta Munirah dan Nurkhin (2018) yaitu kebutuhan memiliki pengaruh positif dan signifikan terhadap kecurangan akademik. Namun penelitian yang dilakukan oleh Budiman (2018) menunjukkan bahwa kebutuhan berpengaruh positif dan tidak signifikan terhadap perilaku kecurangan akademik. Berdasarkan penjelasan diatas, maka perumusan hipotesisnya adalah:

$\boldsymbol{H}_{3}$ : Kebutuhan berpengaruh positif signifikan terhadap kecurangan akademik Pengaruh pengungkapan terhadap kecurangan akademik

Pengungkapan atas suatu tindakan kecurangan dapat membuat seseorang menjadi takut untuk melakukan hal tersebut. Hal ini dikarenakan adanya sanksi yang dapat dikenakan apabila tertangkap melakukan kecurangan. Pernyataan ini didukung oleh hasil penelitian yang dilakukan oleh Munirah dan Nurkhin (2018) serta Budiman (2018) yaitu kebutuhan memiliki pengaruh negatif dan signifikan terhadap tindakan kecurangan akademik. Namun penelitian yang dilakukan oleh Indrawati et al (2017) menunjukan bahwa pengungkapan berpengaruh positif signifikan terhadap perilaku kecurangan akademik. Berdasarkan penjelasan diatas, maka perumusan hipotesisnya adalah:

$\boldsymbol{H}_{4}$ : Pengungkapan berpengaruh negatif signifikan terhadap kecurangan akademik

\section{Pengaruh whistleblower terhadap kecurangan akademik}

Whistleblowing adalah tindakan melaporkan kecurangan yang dilakukan oleh seseorang dari suatu instansi. Whistleblower adalah pihak yang melaporkan kecurangan tersebut. Hasil penelitian yang dilakukan oleh Mustapha dan Siaw (2012) adalah mahasiswa yang bersedia menjadi whistleblower sebagian besar tidak melakukan kecurangan akademik. Akan tetapi berbeda dengan penelitian Bakar et al (2010) ketika mahasiswa lebih memilih jalur aman dengan tidak menjadi whistleblower. Berdasarkan penjelasan diatas, maka perumusan hipotesisnya adalah:

$\boldsymbol{H}_{5}:$ Whistleblower berpengaruh negatif signifikan terhadap kecurangan akademik 


\section{Operasionalisasi variabel}

Berikut adalah tabel 1 mengenai variabel yang digunakan dalam penelitian ini beserta indikator masing-masing variabel:

\section{Tabel 1. Indikator Variabel}

\begin{tabular}{ll}
\hline \multicolumn{1}{c}{ Variabel } & Indikator \\
\hline Keserakahan $\left(\mathrm{X}_{1}\right)$ & (1) Ketidakpuasan atas nilai sendiri \\
Dikembangkan oleh Indrawati et al (2017) & (2) Persaingan yang tinggi \\
& (3) Keinginan untuk lulus dengan cepat \\
Kesempatan $\left(\mathrm{X}_{2}\right)$ & (1) Pengawas ujian yang lengah \\
Dikembangkan oleh Budiman (2018) & (2) Mudahnya akses informasi \\
& (3) Posisi tempat duduk \\
Kebutuhan $\left(\mathrm{X}_{3}\right)$ & (1) Penguasaan materi kurang \\
Dikembangkan oleh Indrawati et al (2017) & (2) Peserta didik malas belajar \\
& (3) Peserta didik membutuhkan nilai yang \\
& tinggi
\end{tabular}

Pengungkapan $\left(\mathrm{X}_{4}\right)$

(1) Tidak ada sanksi yang tegas

Dikembangkan oleh Indrawati et al (2017)

(2) Pembimbing akademik tidak memeriksa absen peserta didik

(3) Tidak ada teman yang pernah tertangkap menyontek

Whistleblower $\left(\mathrm{X}_{5}\right)$

Dikembangkan oleh Mustapha dan Siaw (2012)

(1) Saya pikir whistleblower adalah seorang pahlawan

(2) Saya akan melakukan whistleblowing jika saya benar-benar perlu melakukannya

(3) Whistleblowing menjunjung tinggi moral, praktek etika dan profesionalisme

(4) Whistleblowing dapat mengurangi korupsi, fraud, mismanagement

Kecurangan Akademik (Y)

Dikembangkan oleh

(1) Menyalin tugas milik teman

(2) Memalsukan data kehadiran

(3) Menggunakan gadget saat ujian

(4) Menyiapkan contekan sebelum ujian

(5) Tidak duduk sesuai nomor kursi saat ujian 


\section{Metoda}

\section{Jenis dan Sumber Data}

Penelitian ini menggunakan jenis data kuantitatif untuk meneliti pengaruh indikator GONE Theory terhadap perilaku kecurangan akademik pada mahasiswa Fakultas Ekonomi dan Bisnis (FEB) Program Studi Akuntansi UKRIDA. Selain itu untuk meneliti kesediaan mahasiswa untuk menjadi whistleblower. Sumber data dari penelitian ini menggunakan data primer ketika peneliti mengambil data dengan cara menyebar kuesioner kepada para responden

\section{Populasi dan Sampel}

Populasi dalam penelitian ini adalah mahasiswa S1 FEB Program Studi Akuntansi UKRIDA. Teknik pengambilan sampel menggunakan metode purposive sampling dengan kriteria sebagai berikut: mahasiswa S1 FEB Program Studi Akuntansi UKRIDA dan sudah memiliki Kartu Hasil Studi dari semester sebelumnya. Berdasarkan kriteria tersebut diambil sampel tahun angkatan yang masih aktif yaitu angkatan 2016, 2017, 2018. Adapun angkatan 2019 yang masih aktif tidak dikelompokkan ke dalam sampel karena angkatan 2019 belum memiliki kartu hasil studi pada saat kuesioner penelitian ini dibagikan. Sampel penelitian yang dapat diolah sebanyak 144.

\section{Model Penelitian}

Penelitian ini berjudul "Survei Kecurangan Akademik pada Mahasiswa Program Studi Akuntansi", maka model penelitian dapat digambarkan sebagai berikut:

$$
\mathrm{Y}=\alpha+\beta_{1} \mathrm{X}_{1}+\beta_{2} \mathrm{X}_{2}+\beta_{3} \mathrm{X}_{3}+\beta_{4} \mathrm{X}_{4}+\beta_{5} \mathrm{X}_{5}+€
$$

$\begin{array}{ll}\text { Keterangan: } & \\ \mathrm{Y} & =\text { Kecurangan Akademik } \\ \alpha & =\text { Konstanta } \\ \mathrm{X} 1 & =\text { Keserakahan } \\ \mathrm{X} 2 & =\text { Kesempatan } \\ \mathrm{X} 3 & =\text { Kebutuhan } \\ \mathrm{X} 4 & =\text { Pengungkapan } \\ \mathrm{X} 5 & =\text { Whistleblower } \\ \beta 1-\beta 5 & =\text { Koefisien Regresi } \\ € & =\text { Error }\end{array}$




\section{Metode Analisis Data}

Uji kualitas data terdiri atas uji validitas dan reliabilitas untuk melakukan pengujian data yang menggunakan kuesioner. Uji ini dilakukan agar mengetahui pertanyaan yang diisi oleh responden sudah valid untuk pengumpulan data atau belum.

Uji validitas dilakukan untuk mengetahui valid atau tidaknya indikator. suatu kuesioner. Indikator suatu kuesioner dapat dikatakan valid apabila pertanyaan pada kuesioner dapat mengungkapkan sesuatu yang akan diukur. Kriteria indikator pertanyaan dikatakan valid apabila nilai sig (2-tailed) pada total skor konstruk kurang dari 0,05.

Kuesioner dianggap reliabel atau andal apabila jawaban responden terhadap pertanyaan konsisten atau stabil atas pertanyaan dari variabel tersebut. Kuesioner dinyatakan reliabel apabila memiliki nilai alpha Cronbach lebih dari 0,60.

Uji normalitas dilakukan untuk menguji distribusi data mengikuti atau mendekati distribusi normal, data yang baik dalam penelitian adalah data yang pola distribusinya normal. Uji normalitas dapat dilakukan dengan metode KolmogrovSmirnov test.

Uji multikolenearitas ini bertujuan untuk menguji apakah model regresi ditemukan adanya korelasi antar variabel bebas atau independen. Model regresi yang baik seharusnya tidak terjadi korelasi di antara variabel independen jika variabel independen saling berkorelasi maka variabel ini tidak orthogonal. Variabel orthogonal adalah variabel independen yang nilai korelasi antar sesama variabel independen adalah nol.

Uji heteroskedastisitas bertujuan untuk menguji apakah dalam sebuah model regresi terjadi ketidaksamaan varians dari residual atas satu pengamatan ke pengamatan yang lain. Jika varians dari residual suatu pengamatan ke pengamatan lain tetap, maka disebut homokedastisitas dan jika berbeda disebut heteroskedastisitas.

Koefisien Determinasi digunakan untuk mengukur seberapa jauh model dalam penelitian dalam menjelaskan variasi variabel independen. Apabila nilai (R2) yang rendah berarti adanya keterbatasan kemampuan variabel independen dalam menjelaskan variabel dependen. Apabila nilai (R2) mendekati satu menandakan variabel independen memberikan hampir semua informasi yang dibutuhkan untuk mengukur variabel dependen.

Uji statistik F (uji signifikansi simultan) digunakan untuk menguji apakah semua variabel independen atau bebas di dalam model penelitian memiliki pengaruh secara bersama-sama terhadap variabel dependen atau terikat. Kriteria terdapat pengaruh signifikan antara variabel independen dengan dependen apabila nilai signifikansi lebih kecil dari 0,05. 
Uji statistik t (uji signifikansi simultan) digunakan untuk menguji seberapa jauh pengaruh satu variabel independen secara individual dalam menjelaskan variasi variabel dependen. Pada prosedur uji probabilitas statistik t atau nilai $\mathrm{p}$ hanya membandingkan nilai probabilitas $p$ dengan nilai signifikansi $\alpha$ yang dipilih. Bila sig. lebih dari 0,05 atau 0,1 berarti variabel independen berpengaruh tidak signifikan terhadap variabel dependen. Sedangkan apabila sig. kurang dari 0,05 atau 0,1 berarti variabel independen berpengaruh signifikan terhadap variabel dependen.

\section{Hasil dan Pembahasan}

\section{Hasil}

\section{Demografi Responden}

Objek di dalam penelitian ini adalah mahasiswa aktif dari Program Studi Akuntansi Universitas Kristen Krida Wacana yang telah mendapatkan Kartu Hasil Studi dari semester sebelumnya. Berdasarkan kriteria tersebut, responden yang memenuhi kriteria tersebut adalah mahasiswa Program Studi Akuntansi dari angkatan 2016, 2017, dan 2018. Jumlah kuesioner yang disebar sebanyak 147 kuesioner dengan cara menyebarkan kuesioner fisik langsung kepada para responden. Terdapat 3 kuesioner yang tidak dapat dimasukkan dalam pengolahan data dikarenakan pengisiannya tidak lengkap.

Terdapat 144 kuesioner yang dapat dilanjutkan ke tahap pengolahan data, diketahui bahwa 97 responden adalah wanita dan 47 responden adalah pria. Berdasarkan semester, 56 responden merupakan mahasiswa semester 3 (angkatan 2018), 44 responden mahasiswa semester 5 (angkatan 2017), dan 44 responden mahasiswa semester 7 (angkatan 2016). Dalam penelitian ini sampel didominasi dengan responden mahasiswa semester 3. Berdasarkan IPK, 34 responden memiliki IPK kurang dari 3.00, 81 responden memiliki IPK 3.00 - 3.50 dan 29 responden memiliki IPK lebih dari 3.50.

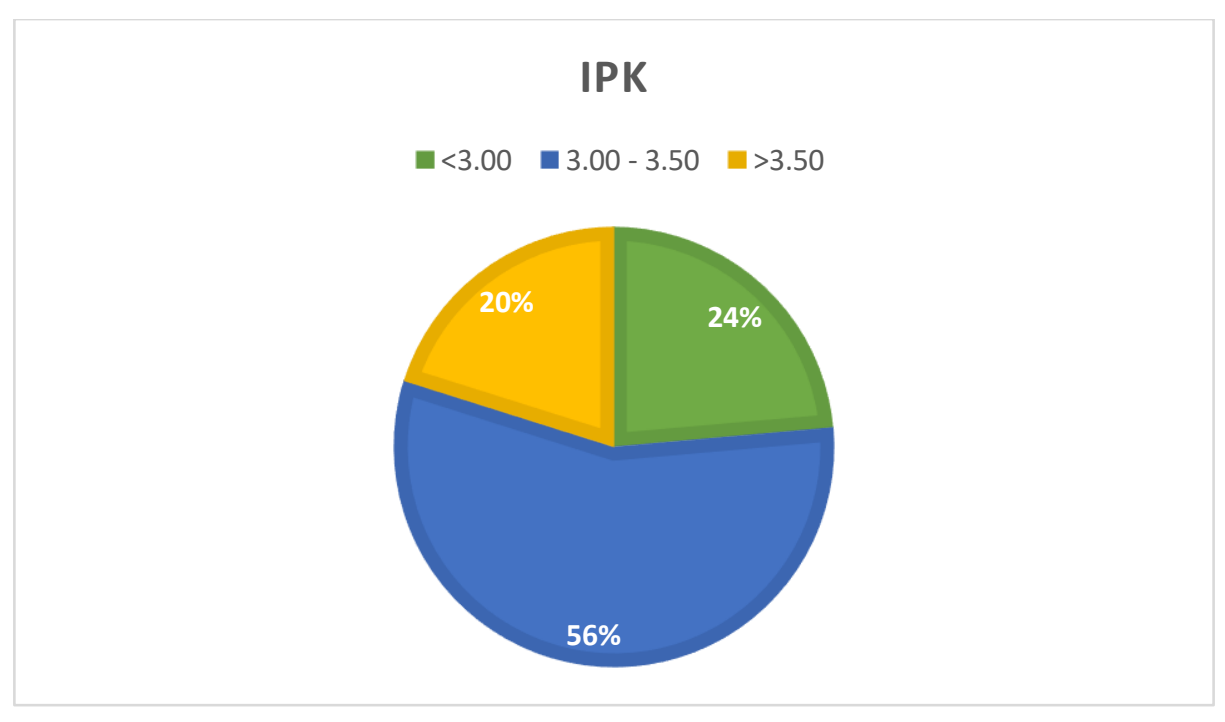

Gambar 1. Demografi Sebaran IPK 


\section{Hasil Uji Data Penelitian}

Berdasarkan hasil uji validitas dapat diambil kesimpulan bahwa seluruh indikator pertanyaan yang digunakan dalam penelitian ini adalah valid, hal tersebut dapat dilihat dari nilai Sig. (2-tailed) setiap indikator kurang dari 0,05. Sedangkan hasil uji reliabilitas menunjukkan bahwa seluruh variabel memiliki nilai Cronbach's Alpha lebih besar 0,60 yang berarti telah reliabel, sehingga layak digunakan menjadi alat ukur instrumen kuesioner dalam penelitian ini.

Pada hasil uji normalitas menunjukkan nilai Asymp.Sig (2-tailed) sebesar 0.200. Dari hasil tersebut dapat diambil kesimpulan bahwa model regresi penelitian ini berdistribusi normal karena lebih besar dari 0,05 maka model regresi dalam penelitian ini layak digunakan. Hasil uji multikolinearitas menunjukkan nilai tolerance dari kelima variabel independen lebih dari 0,10 dan VIF kurang dari 10. Maka dari itu dapat diambil kesimpulan bahwa model regresi dalam penelitian ini terbebas dari kasus multikolinearitas sehingga layak digunakan.

Hasil uji heteroskedastisitas menunjukkan bahwa sebaran titik tidak membentuk suatu pola atau alur tertentu, hal itu dikarenakan titik data menyebar diatas dan dibawah atau disekitar angka 0 maka dapat disimpulkan tidak terjadi masalah heteroskedastisitas.

Berdasarkan tabel 2 diketahui bahwa besarnya adjusted $R$ Square atau angka koefisien determinasi $\left(\mathrm{R}^{2}\right)$ sebesar 0,554 atau 55,4\%. Hal ini berarti bahwa variabel keserakahan, kesempatan, kebutuhan, pengungkapan, dan whistleblower mempengaruhi variabel kecurangan akademik sebesar 55,4\%. Sedangkan sisanya $(100 \%-55,4 \%=44,6 \%)$ dipengaruhi oleh variabel lain diluar model regresi ini.

\section{Tabel 2. Hasil Uji $\mathbf{R}^{2}$}

\begin{tabular}{lllll}
\hline Model & R & R Square & Adjusted R Square & Std. Error of the Estimate \\
\hline 1 & $.755^{\mathrm{a}}$ & .570 & .554 & 1.977 \\
\hline
\end{tabular}

Berdasarkan hasil perhitungan pada tabel 3 hasil dari uji F, nilai signifikan sebesar 0.000 yang berarti lebih kecil dari tingkat signifikan $(\alpha)$ sebesar $5 \%$. Dengan demikian variasi nilai variabel bebas atau variabel independen dapat menjelaskan variasi nilai dependen. Sehingga variabel keserakahan, kesempatan, kebutuhan, pengungkapan, dan whistleblower secara bersama-sama (simultan) berpengaruh terhadap kecurangan akademik.

\section{Tabel 3. Hasil Uji F}

ANOVA $^{a}$

\begin{tabular}{llllll}
\hline Model & Sum of Squares & df & Mean Square & F & Sig. \\
\hline${ }^{1}$ Regression & 745.545 & 5 & 149.109 & 38.728 & $.000^{\mathrm{b}}$ \\
Residual & 542.877 & 141 & 3.850 & & \\
Total & 1288.422 & 146 & & & \\
\hline
\end{tabular}


Berdasarkan tabel 3 dapat disimpulkan sebagai berikut:

Konstanta sebesar 3.733 dalam tabel 4 menunjukkan variabel-variabel independen (keserakahan, kesempatan, kebutuhan, pengungkapan dan whistleblower) diasumsikan tidak mengalami perubahan (konstan) maka nilai Y (kecurangan akademik) adalah sebesar 3,733 \%. Koefisien uji t keserakahan adalah 0,391 dan nilai signifikansinya adalah 0,005 yang berarti keserakahan berpengaruh positif signifikan terhadap kecurangan akademik. Sehingga hipotesis pertama diterima.

Koefisien uji t kesempatan adalah 0,196 dan nilai signifikansinya adalah 0,062 yang berarti kesempatan berpengaruh positif signifikan terhadap kecurangan akademik. Sehingga hipotesis kedua diterima. Koefisien uji t kebutuhan adalah 0,077 dan nilai signifikansinya adalah 0,568 yang berarti kebutuhan berpengaruh positif tidak signifikan terhadap kecurangan akademik. Sehingga hipotesis ketiga ditolak. Koefisien uji t pengungkapan adalah 0,557 dan nilai signifikansinya adalah 0,000 yang berarti pengungkapan berpengaruh positif signifikan terhadap kecurangan akademik. Sehingga hipotesis keempat ditolak. Koefisien uji t whistleblower adalah 0,010 dan nilai signifikansinya adalah 0,865 yang berarti whistleblower berpengaruh negatif tidak signifikan terhadap kecurangan akademik. Sehingga hipotesis kelima ditolak.

\section{Tabel 4. Hasil Uji t}

\begin{tabular}{|c|c|c|c|}
\hline Model & $\begin{array}{l}\text { Unstandardized } \\
\text { Coefficients } \\
\mathrm{B}\end{array}$ & Sig. & Kesimpulan \\
\hline Constant & 3.733 & 0.000 & \\
\hline Keserakahan & .391 & $0.005^{*}$ & $\mathrm{H}_{1}$ diterima \\
\hline Kesempatan & .196 & $0.062^{* *}$ & $\mathrm{H}_{2}$ diterima \\
\hline Kebutuhan & .077 & 0.568 & $\mathrm{H}_{3}$ ditolak \\
\hline Pengungkapan & .557 & $0.000^{*}$ & $\mathrm{H}_{4}$ ditolak \\
\hline Whistleblower & -.010 & 0.865 & $\mathrm{H}_{5}$ ditolak \\
\hline
\end{tabular}

* Sign pada $5 \%$

** Sign pada $10 \%$

\section{Pembahasan}

\section{Pengaruh Keserakahan Terhadap Kecurangan Akademik}

Pengujian dilakukan melalui signifikansi koefisien regresi variabel keserakahan. Keserakahan memiliki nilai koefisien positif sebesar 0,391 dan sig. tailed sebesar 0,005 . Dengan demikian berarti keserakahan berpengaruh positif signifikan terhadap kecurangan akademik mahasiswa Program Studi Akuntansi Fakultas Ekonomi dan Bisnis Universitas Kristen Krida Wacana (FEB UKRIDA).

Hasil penelitian ini berbeda dengan penelitian Budiman (2018), ketika pada penelitian tersebut keserakahan berpengaruh positif tidak signifikan terhadap kecurangan akademik. Namun hasil penelitian ini sesuai dengan Indrawati et al. (2017) serta Munirah dan Nurkhin (2018). Pada penelitian ini keserakahan berpengaruh positif dan signifikan, berarti keserakahan berperan penting dalam 
terjadinya kecurangan akademik di kalangan mahasiswa Program Studi Akuntansi FEB UKRIDA.

Faktor keserakahan adalah faktor yang berhubungan langsung dengan perilaku setiap individu, hal tersebut bisa dikarenakan adanya ketidakpuasan terhadap IPK yang dimiliki sekarang, keinginan untuk lulus suatu mata kuliah, serta tidak ingin nilai temannya lebih tinggi dibanding nilainya.

\section{Pengaruh Kesempatan Terhadap Kecurangan Akademik}

Pengujian dilakukan melalui signifikansi koefisien regresi variabel kesempatan ketika variabel tersebut memiliki nilai koefisien positif sebesar 0,196 dan sig. tailed sebesar 0,062. Dengan demikian berarti kesempatan berpengaruh positif signifikan terhadap kecurangan akademik mahasiswa Program Studi Akuntansi Fakultas Ekonomi dan Bisnis Universitas Kristen Krida Wacana (FEB UKRIDA). Hasil penelitian ini berbeda dengan penelitian Budiman (2018), ketika pada penelitian tersebut kesempatan berpengaruh positif tidak signifikan terhadap kecurangan akademik. Namun hasil penelitian ini sesuai dengan penelitian Indrawati et al. (2017) serta Munirah dan Nurkhin (2018).

Pada penelitian ini kesempatan berpengaruh positif signifikan, berarti kesempatan berpengaruh terhadap kecurangan akademik pada mahasiswa Program Studi Akuntansi FEB UKRIDA. Dari hasil penelitian menunjukkan pengawasan yang tidak ketat pada saat ujian sehingga terdapat kesempatan untuk melakukan kecurangan, ditambah mahasiswa tersebut duduk ditempat yang tidak terlihat oleh pengawas sehingga mempermudah mahasiswa untuk melakukan kecurangan.

\section{Pengaruh Kebutuhan Terhadap Kecurangan Akademik}

Pengujian dilakukan melalui signifikansi koefisien regresi variabel kesempatan ketika variabel tersebut memiliki nilai koefisien positif sebesar 0,077 dan sig. tailed sebesar 0,568. Dengan demikian berarti kebutuhan berpengaruh positif tidak signifikan terhadap kecurangan akademik mahasiswa Program Studi Akuntansi Fakultas Ekonomi dan Bisnis Universitas Kristen Krida Wacana (FEB UKRIDA).

Hasil penelitian ini berbeda dengan penelitian Indrawati et al. (2017) serta Munirah dan Nurkhin (2018), ketika pada penelitian tersebut kebutuhan berpengaruh positif signifikan terhadap kecurangan akademik. Namun hasil penelitian ini sesuai dengan penelitian Budiman (2018) ketika pada penelitian ini kebutuhan berpengaruh positif dan tidak signifikan. Hal ini menunjukkan bahwa mahasiswa sudah cukup menguasai materi ujian dari suatu mata kuliah sehingga tidak perlu melakukan kecurangan. Selain itu mahasiswa tidak terpacu untuk mendapatkan IPK tinggi dengan cara yang salah yaitu dengan melakukan kecurangan. 


\section{Pengaruh Pengungkapan Terhadap Kecurangan Akademik}

Pengujian dilakukan melalui signifikansi koefisien regresi variabel pengungkapan ketika variabel tersebut memiliki nilai koefisien positif sebesar 0,557 dan sig. tailed sebesar 0,000. Dengan demikian berarti pengungkapan berpengaruh positif signifikan terhadap kecurangan akademik mahasiswa Program Studi Akuntansi Fakultas Ekonomi dan Bisnis Universitas Kristen Krida Wacana (FEB UKRIDA).

Hasil penelitian ini berbeda dengan penelitian Budiman (2018) serta Munirah dan Nurkhin (2018), ketika pada penelitian tersebut pengungkapan berpengaruh negatif signifikan terhadap kecurangan akademik. Namun hasil penelitian ini sesuai dengan penelitian Indrawati et al. (2017) ketika pada penelitian ini kebutuhan berpengaruh positif dan signifikan. Dari hasil tersebut dapat ditarik kesimpulan bahwa tidak terdapat sanksi yang tegas di Universitas sehingga mahasiswa tetap melakukan kecurangan akademik. Hal tersebut didorong juga oleh faktor mahasiswa yang merasa dirinya aman karena teman sesama mahasiswanya pun tidak pernah tertangkap melakukan kecurangan.

\section{Pengaruh Whistleblower Terhadap Kecurangan Akademik}

Pengujian dilakukan melalui signifikansi koefisien regresi variabel pengungkapan ketika variabel tersebut memiliki nilai koefisien positif sebesar -0,010 dan sig. tailed sebesar 0,865. Dengan demikian berarti whistleblower berpengaruh negatif tidak signifikan terhadap kecurangan akademik mahasiswa Program Studi Akuntansi Fakultas Ekonomi dan Bisnis Universitas Kristen Krida Wacana (FEB UKRIDA).

Hasil penelitian ini berbeda dengan penelitian Mustapha dan Siaw (2012), ketika pada penelitian tersebut whistleblower berpengaruh negatif signifikan terhadap kecurangan akademik. Namun hasil penelitian ini sesuai dengan penelitian Bakar et al. (2010) ketika pada penelitian ini whistleblower berpengaruh negatif dan tidak signifikan.

Dari hasil tersebut menunjukkan mahasiswa mengetahui bahwa whistleblower memang dapat menurunkan angka kecurangan, akan tetapi saat mereka mengetahui kecurangan mereka memilih sisi aman dengan tidak menjadi whistleblower. Hal tersebut dapat dikarenakan mereka takut dikucilkan teman seangkatan ataupun takut dirinya terancam karena telah melaporkan kecurangan.

\section{Simpulan}

Berdasarkan hasil analisis dan pembahasan sebagaimana telah dipaparkan pada bab sebelumnya, maka dapat diambil kesimpulan sebagai berikut: (1) Dari 5 variabel yang diuji terdapat 3 variabel yang berpengaruh signifikan yaitu variabel keserakahan, kesempatan dan pengungkapan. Dengan 3 variabel tersebut berpengaruh positif signifikan terhadap kecurangan akademik. Hipotesis dari variabel keserakahan dan kesempatan diterima, sedangkan hipotesis variabel pengungkapan ditolak. (2) 
Terdapat 2 variabel yang berpengaruh tidak signifikan yaitu variabel kebutuhan dan whistleblower. Variabel kebutuhan berpengaruh positif tidak signifikan dan variabel whistleblower berpengaruh negatif tidak signifikan. Oleh karena itu, hipotesis dari 2 variabel tersebut ditolak.

Penelitian ini masih memiliki beberapa keterbatasan. Dikarenakan keterbatasan tersebut, terdapat beberapa saran yang dapat digunakan oleh peneliti selanjutnya apabila ingin melanjutkan penelitian ini: (1) Ruang lingkup penelitian ini hanya pada mahasiswa dari Universitas Kristen Krida Wacana (UKRIDA) saja, sehingga hasil penelitian ini tidak dapat digeneralisir untuk Universitas lain. Maka peneliti selanjutnya dapat menggunakan sampel dari Universitas lain agar hasilnya dapat dibandingkan dengan hasil penelitian di UKRIDA, seperti pada penelitian yang dilakukan Munirah dan Nurkhin (2018) dengan judul Pengaruh Faktor-Faktor Fraud Diamond dan GONE Theory Terhadap Kecurangan Akademik. (2) Variabel untuk mengukur motivasi melakukan kecurangan akademik hanya mengadopsi konsep GONE Theory. Peneliti selanjutnya dapat mengambil konsep dari Fraud Pentagon ketika teori tersebut merupakan teori terbaru dalam mendeteksi motivasi untuk melakukan fraud. Penelitian ini selanjutnya dapat mengambil referensi dari jurnal dengan judul Fraudulence Financial Statements Analysis using Pentagon Fraud Approach oleh Triyanto (2019). (3) Adapun mahasiswa yang berpartisipasi dalam penelitian ini hanya mahasiswa dari Program Studi Akuntansi. Alangkah baiknya jika peneliti selanjutnya menambah responden dari Program Studi lain seperti pada penelitian Purnamasari (2013) yang berjudul Faktor-faktor yang Mempengaruhi Kecurangan Akademik pada Mahasiswa.

\section{Daftar Pustaka}

Albrecht, W., Albrecht, C., Albrecht, C., \& Zimbelman, M. (2012). Fraud Examination Fourth Edition. South-Western: Cengage Learning.

Artantri, L. R., Handajani, L., \& Pituringsih, E. (2016). Peran E-Procurement Terhadap Pencegahan Fraud pada Pengadaan Barang/Jasa Pemerintah Daerah di Pulau Lombok. Journal NeO-Bis Volume 10, No 1, 16-32.

Bakar, N. B., Ismail, S., \& Mamat, S. (2010). Will Graduating Year Accountancy Students Cheat in Examination. International Education Studies Vol. 3 No. 3, 145-152.

Budiman, N. A. (2018). Perilaku Kecurangan Akademik Mahasiswa: Dimensi Fraud Diamond dan Gone Theory. Jurnal Ilmu Akuntansi Vol. 11 (1), 75-90.

Dewi, G. R. (2016). Pengaruh Moralitas Individu dan Pengendalian Internal Pada Kecurangan Akuntansi (Studi Eksperimen pada Pemerintah Daerah Bali). Jurnal Ilmiah Akuntansi Vol.1 No. 1, 2-3.

Elias, R. (2019). The Relationship Between Self-Interest VS Other-Interest and Business Students Perceptions of Cheating Ethics. Social Science Research Network.

Indrawati, G. A., Purnamawati, I. A., \& Tunggaatmadja, A. W. (2017). Pengaruh Greed, Opportunity, Need, Exposure Terhadap Perilaku Kecurangan Akademik pada 
Mahasiswa Akuntansi Program S1 Negeri di Bali. Journal S1 Ak Universitas Pendidikan Ganesha Vol. 8 No. 2, 1-8.

Isgiyata, J., Indayani, \& Budiyoni, E. (2018). Studi Tentang Teori Gone dan Pengaruhnya Terhadap Fraud Dengan Idealisme Pimpinan Sebagai Variabel Moderasi: Studi Pada Pengadaan Barang/Jasa di Pemerintahan. Jurnal Dinamika Akuntansi dan Bisnis Vol. $5(1), 31-42$.

Munirah, A., \& Nurkhin, A. (2018). Pengaruh Faktor-Faktor Fraud Diamond dan GONE Theory Terhadap Kecurangan Akademik. Economic Education Analysis Journal 7 (1), 120139.

Mustapha, M., \& Siaw, L. S. (2012). Will Final Year Accountancy Students Whistle Blow? A Malaysian Case. International Journal of Trade, Economics and Finance, Vol.3 No. 5, 327-331.

Nurharjanti, N. N. (2017). Persepsi Mahasiswa Dalam Mengurangi Fraud Akademik: Whistleblowing Sistem. Jurnal Akuntansi dan Bisnis Vol. 17 No. 1, 1-12.

Purnamasari, D. (2013). Faktor-faktor yang Mempengaruhi Kecurangan Akademik pada Mahasiswa. Educational Psychology Journal Vol.2 No. 1, 13-21.

Ratnawati, T., Salean, D., \& Maqsudi, A. (2016). Mendeteksi Kecurangan Laporan Keuangan Perusahaan. Jurnal Ekonomi dan Bisnis Vol. 1 No. 1, 121-132.

Triyanto, D.N. (2019). Fraudulence Financial Statement Analysis using Pentagon Fraud Approach. Journal of Accounting Auditing and Business Vol. 2 No.2, 26-36.

Winardi, R. D., Mustikarini, A., \& Anggraeni, M. A. (2017). Academic Dishonesty Among Accounting Students: Some Indonesian Evidence. Jurnal Akuntansi dan Keuangan Indonesia Vol. 14 No. 2, 142-164. 
